\title{
Diagnostic labels of NANDA-I in a southern region of Spain
}

\author{
Rafael González-Rodríguez ${ }^{1}$ \\ María de los Ángeles Martelo-Baro ${ }^{1}$ \\ Pilar Bas-Sarmiento ${ }^{1}$
}

\begin{abstract}
Objective: to determine the incidence of NANDA-I diagnostic labels (North American Nursing Diagnosis Association-International) and to establish the distribution of cases of assistance and the associated labels, according to sociodemographic variables (age and sex). Method: descriptive, cross-sectional epidemiological study of labels of NANDA-I, under ecological design. The distribution of labels was analyzed according to sex and age; the corresponding frequencies were calculated and for each label the incidence were calculated rates with aggregate data from the attended cases. Results: the total number of cases of care under study was 9,928 (41.65\% men and 58.35\% women). The identified labels were 16,456 (7,084 men and 9,372 women); average of 1.7 labels per case of care; Out of 216 labels proposed by NANDA-I, in its 2012-14 classification, 152 were used, representing 70.4\%. The labels with the highest incidence rates per thousand inhabitants were: Anxiety, Willingness to Improve Knowledge and Risk of Infection. Conclusions: the study allowed detecting, through NANDA-I, the answers to the health problems of greater incidence in the users attended.
\end{abstract}

Descriptors: Research; Nursing Diagnosis; Epidemiological Studies.

${ }^{1}$ PhD, Professor, Departamento de Enfermería y Fisioterapia, Facultad de Enfermería, Universidad de Cádiz, Cádiz, Spain.

\section{How to cite this article}

González-Rodríguez R, Martelo-Baro MA, Bas-Sarmiento P. Diagnostic labels of NANDA-I in a southern region of Spain. Rev. Latino-Am. Enfermagem. 2017;25:e2911. [Access DOI: http://dx.doi.org/10.1590/1518-8345.1714.2911. ]; Available in: 


\section{Introduction}

The nursing diagnosis is the clinical judgment about the response of an individual, family or community to a vital process/problem of health, real or potential that nurses identifies, validates and treats independently ${ }^{(1)}$.

The development and classification of nursing diagnoses have elapsed during a period of identification and description of nurses' perceptions of health problems of users, based on research and consensus in different contexts of practice of new proposals for diagnosis and by reviewing of existing ones ${ }^{(2)}$; and has contributed to identifying human responses to health problems and life processes and to describing the needs that users are experiencing.

There are different approaches to quantify and qualify these problems and health needs of populations. Each of them makes specific contributions and also has its own limitations. It is possible to make inferences from censuses, vital statistics, population rates and other methods. Through the users' perception of their health, it is possible to measure symptoms, illnesses, injuries and disabilities; this also can be made with objective measurements of physical and mental functions, or with vital signs and biochemical levels, among other determinations. Among these approaches, epidemiological studies are usually applied; its purpose is to estimate factors such as: the global magnitude of a problem; the impact on health; the integrity of health services; and the specific health care needs of individuals, among others ${ }^{(3)}$. Epidemiological studies on nursing diagnoses are designed to document the frequency or prevalence of these in a given population.

With these premises - following the recommendations of the International Council of Nursing(4) (nursing research priorities for the present century) and given the validity of NANDA-I diagnoses (epidemiological studies of the incidence and prevalence of specific diagnoses in certain settings and populations( $\left.{ }^{(2)}\right)$ - we have proposed the following objective described below.

\section{Objective}

To determine the incidence of NANDA-I diagnostic labels - in the Municipal Health Management Area " $L a$ Línea de la Concepción" (Cadiz, Andalusia, Spain) - by establishing the distribution of care cases and their labels, according to socio demographic variables (age and sex).

\section{Material and Method}

This is a descriptive, cross-sectional epidemiological study of the NANDA-I diagnostic labels, under an ecological design, that is to say, based on groups of a specific population as a unit of study, from which the rates of disease and some other characteristics were compared. A total of 13,587 care cases were studied, of which 3,659 were excluded because of the criteria below, which occurred in the Sanitary Management Area of La Línea de la Concepción municipality (Cadiz, Andalusia, Spain), which is composed of a general hospital and 3 primary health care centers. The study was conducted between January 1 and December 31, 2014; were extracted from each computerized nursing record, the following variables: sex, age and the assigned diagnostic labels (according to NANDA-I Classification, in the version 2012-2014) that were issued during hospital admissions or in the first consultation.

We understand by clinical case the clinical history generated by health professionals every time a patient is treated in a hospital or health center.

It was performed the analysis distribution of different diagnostic labels according to sex and age; the corresponding frequencies were calculated and for each diagnostic label was estimated the incidence rates with aggregated data from care cases attended.

The data were obtained from a secondary source, through a Database created by the Information Technologies and Systems Service of the Health Management Area of La Línea de la Concepción municipality; to process data and to perform the subsequent statistical analysis was used the software Microsoft Excel 2013 and IBM SPSS Statistics 20.

Due to the fact that it was worked with the total number of officially registered care cases, the total municipality population was taken as reference. Data from the census population corresponding to 2014, were obtained from the National Institute of Statistics Database. The age groups were classified according to the values proposed by NANDA-I (2015-2017).

The following exclusion criteria were used:

- Clinical records belonging to persons not resident in $L a$ Linea de la Concepcion municipality.

- Clinical records that did not have at least one nursing diagnosis.

This study was carried out in accordance with the ethical standards established in the Declaration of Helsinki and also followed the recommendations of Good Clinical Practice of the European Community (document 111/3976/88 of July 1990); the Spanish legal regulations on data confidentiality were complied (Organic Law 15/1999 of December 13, on Protection of personal data). Approval was also obtained from the Clinical Research Ethics Committee of the Hospital Puerto Real, Bahía de Cadiz, La Janda and Campo de Gibraltar (file number 11_12). 


\section{Results}

The total number of care cases was 9,928 , with a mean age of 56.63 years $(S D=27.23)$. The mean age of men was 55.09 years and of women 57.94 years; Table 1 shows its distribution by sex, age group and male/female ratio.

To have an idea of the magnitude of the problem, the care cases were related to the projection of population for each age group. The distribution of population for age groups is presented in Table 2.

Incidence rates were calculated with aggregate data from care cases by age group; to estimate the margin of error, the corresponding confidence interval was calculated with a significance level of $95 \%$. The results are presented in Table 3, in which the denominators employed are the projections of the population in the middle of the period, on July 1,2014 , provided by the National Institute of Statistics.

The total number of diagnostic labels identified in the care cases was $16,456[7,084(43.05 \%)$ men and 9,372 (56.95\%) women] with an average of 1.7 labels per case; out of 216 labels proposed by NANDA-I, in its 2012-14 classification, 152 were used, representing $70.4 \%$. The analysis of main diagnostic labels was performed by calculating the observed frequency, percentages and incidence rates; thus, the most representative labels from the total were selected according to sex (table 4) and according to age group (Table 5).

Table 1 - Distribution of care cases by age group, sex and male/female ratio. La Línea de la Concepción, Cadiz, Spain, 2014

\begin{tabular}{|c|c|c|c|c|c|}
\hline \multirow{2}{*}{ Age groups } & \multicolumn{2}{|c|}{ Care cases } & \multirow{2}{*}{ Total } & \multirow{2}{*}{ Percentage } & \multirow{2}{*}{$\mathbf{R} \mathbf{M} / \mathbf{W}^{*}$} \\
\hline & Men & Women & & & \\
\hline Breast-feeding & 74 & 129 & 203 & $2 \%$ & 0.57 \\
\hline Children & 234 & 233 & 467 & $4.7 \%$ & 1 \\
\hline Adolescent & 182 & 193 & 375 & $3.8 \%$ & 0.94 \\
\hline Adults & 1,641 & 2,139 & 3,780 & $38.1 \%$ & 0.76 \\
\hline Elderly & 2,004 & 3,099 & 5,103 & $51.4 \%$ & 0.64 \\
\hline Total & 4,135 & 5,793 & 9,928 & 100 & 0.71 \\
\hline
\end{tabular}

*R M/W: Ratio Man/Woman

Table 2 - Population attached to the different age groups of La Línea de la Concepción Municipality (Cadiz, Spain). Population projection year 2014

\begin{tabular}{|c|c|c|c|c|}
\hline \multirow{2}{*}{ Age groups } & \multicolumn{2}{|c|}{ Habitants } & \multirow{2}{*}{ Total habitants } & \multirow{2}{*}{ Percentage } \\
\hline & Men & Women & & \\
\hline Breast-feeding & 370 & 353 & 723 & 1.1 \\
\hline Children & 3,766 & 3,429 & 7,195 & 11 \\
\hline Adolescent & 3,867 & 3,538 & 7,405 & 11.3 \\
\hline Adults & 20,240 & 19,937 & 40,177 & 61.4 \\
\hline Elderly & 4,301 & 5,624 & 9,925 & 15.2 \\
\hline Total & 32,544 & 32,881 & 65,425 & 100 \\
\hline
\end{tabular}

Table 3 - Care cases, projection of population in the middle of the period and incidence rate (people, follow-up period). La Línea de la Concepción, Cadiz, Spain, 2014

\begin{tabular}{|c|c|c|c|c|c|}
\hline Age groups & $\mathrm{CC}^{*}$ & $\mathrm{PP}^{\dagger}$ & $\mathbf{I R}^{\ddagger}$ & IR per 1000 people & $\begin{array}{c}\mathrm{Cl}^{\S}(95 \%) \\
\text { IR per } 1000 \text { people }\end{array}$ \\
\hline Breast-feeding & 203 & 723 & 0.28077 & 280.77 & $270.1-291.5$ \\
\hline Children & 467 & 7,195 & 0.06490 & 64.90 & $42.5-87.3$ \\
\hline Adolescent & 375 & 7,405 & 0.05064 & 50.64 & $25.4-75.9$ \\
\hline Adults & 3,780 & 40,177 & 0.09408 & 94.08 & $75.6-112.5$ \\
\hline Elderly & 5,103 & 9,925 & 0.51415 & 514.15 & $506.3-522$ \\
\hline Total & 9,928 & 65,425 & 0.15174 & 151.74 & $137.2-166.3$ \\
\hline
\end{tabular}

*CC: Care Cases; †PP: Population Projection; ¥IR: Incidence Rate; §CI: Confidence interval. 
Table 4 - Observed frequency, percentage and incidence rates of main diagnostic labels in the total care cases by sex. La Línea de la Concepción, Cadiz, Spain, 2014

\begin{tabular}{|c|c|c|c|c|c|c|c|c|c|}
\hline \multirow{2}{*}{ Diagnostic label } & \multicolumn{3}{|c|}{ Total } & \multicolumn{3}{|c|}{ Men } & \multicolumn{3}{|c|}{ Women } \\
\hline & Fo* & $\%^{\dagger}$ & $\mathbf{I R}^{\ddagger}$ & Fo* & $\%^{\dagger}$ & $\mathrm{TI}^{\ddagger}$ & Fo* & $\%^{\dagger}$ & $\mathbf{I R}^{\ddagger}$ \\
\hline Anxiety & 1.488 & 15 & 22,7 & 626 & 15,1 & 19,2 & 862 & 14,9 & 26,2 \\
\hline Willingness to improve knowledge & 1.152 & 11,6 & 17,6 & 508 & 12,3 & 15,6 & 644 & 11,1 & 19,5 \\
\hline Risk of Infection & 1.127 & 11,4 & 17,2 & 495 & 12 & 15,2 & 632 & 10,9 & 19,2 \\
\hline
\end{tabular}

*Fo: Observed Frequency; $+\%$ : Percentage; ¥IR: Incidence Rate

Table 5 - Distribution of main diagnostic labels by each age group and sex. La Línea de la Concepción, Cadiz, Spain, 2014

\begin{tabular}{|c|c|c|c|c|c|c|c|c|c|}
\hline \multirow{3}{*}{ Diagnostic label } & \multicolumn{6}{|c|}{ Breast-feeding: $\geq 28$ days and $<1$ year } & \multirow{2}{*}{\multicolumn{3}{|c|}{ Women }} \\
\hline & \multicolumn{3}{|c|}{ Total } & \multicolumn{3}{|c|}{ Men } & & & \\
\hline & Fo* & $\%^{\dagger}$ & $\mathbf{I R}^{\ddagger}$ & Fo* & $\%^{\dagger}$ & $\mathbf{I R}^{\ddagger}$ & Fo* & $\%^{\dagger}$ & $\mathbf{I R}^{\ddagger}$ \\
\hline Effective breastfeeding & 46 & 22,7 & 63,6 & 17 & 23 & 46 & 29 & 22,5 & 82,2 \\
\hline Risk of Infection & 30 & 14,8 & 41,5 & 12 & 16,2 & 32,4 & 18 & 14 & 51 \\
\hline Anxiety & 23 & 11,3 & 31,8 & 9 & 12,2 & 24,3 & 14 & 10,9 & 39,7 \\
\hline \multicolumn{10}{|c|}{ Children: between 1 and 9 years old, both included } \\
\hline Risk of Infection & 71 & 15,2 & 9,9 & 37 & 15,8 & 9,8 & 34 & 14,6 & 9,9 \\
\hline Anxiety & 56 & 12 & 7,8 & 23 & 9,8 & 6,1 & 33 & 14,2 & 9,6 \\
\hline Degradation of physic mobility & 23 & 4,9 & 3,2 & 12 & 5,1 & 3,2 & 11 & 4,7 & 3,2 \\
\hline \multicolumn{10}{|c|}{ Adolescent: between 10 and 19 years old, both included } \\
\hline Willingness to improve knowledge & 100 & 26,7 & 13,5 & 40 & 22 & 10,3 & 60 & 31,1 & 17 \\
\hline Anxiety & 58 & 15,5 & 7,8 & 24 & 13,2 & 6,2 & 34 & 16,6 & 9,6 \\
\hline Poor knowledge & 44 & 11,7 & 5,9 & 17 & 9,3 & 4,4 & 27 & 14 & 7,6 \\
\hline \multicolumn{10}{|c|}{ Adults: between 20 and 64 years old, both included } \\
\hline Willingness to improve knowledge & 773 & 20,4 & 19,2 & 333 & 20,3 & 16,5 & 440 & 20,6 & 22,1 \\
\hline Anxiety & 753 & 19,9 & 18,7 & 333 & 20,3 & 16,4 & 420 & 19,6 & 21,1 \\
\hline Risk of Infection & 463 & 12,2 & 11,6 & 207 & 12,6 & 10,2 & 256 & 12 & 12,9 \\
\hline \multicolumn{10}{|c|}{ Elderly: $\geq 65$ years old } \\
\hline Anxiety & 598 & 11,7 & 60,3 & 237 & 11,8 & 55,1 & 361 & 11,6 & 64,2 \\
\hline Intolerance to activity & 551 & 10,8 & 55,5 & 235 & 11,7 & 54,6 & 316 & 10,2 & 56,2 \\
\hline Degradation of physic mobility & 535 & 10,5 & 53,9 & 236 & 11,8 & 54,9 & 299 & 9,6 & 53,2 \\
\hline
\end{tabular}

*Fo: Observed Frequency; +\%: Percentage; ¥IR: Incidence Rate

\section{Discussion}

Average of diagnostic labels per each care case was well below those found in other studies, in which the average ranged from 8.7 to 4.2 diagnoses per patient ${ }^{(5-7)}$. The following causes could justify the low average of diagnostic labels, identified by each care case: pressure to incorporate into the praxis the use of a record of nursing diagnoses, accompanied by a lack of training; excessive workload; weak development of the independent role; limited ability of NANDA-I diagnoses to adapt to different care situations; complexity in the structure of NANDA-I that makes it difficult to manage; and use of a little understandable language.

The main and more frequent diagnostic label obtained by the analysis was the Anxiety label; it also appeared among the top three in all age groups.

The anxiety label refers to a situation in which the person experiences a vague and uneasy feeling of discomfort or threat, accompanied by an autonomous response (often the origin of this feeling is unspecific or unknown to the person); it is a warning sign that indicates an imminent danger and allows the person to take action to face the threat ${ }^{(8)}$.

It is advisable to use this label when the person suffers a severe anxiety, that is to say, the third level of the four that have been classically described: mild, moderate, severe and panic ${ }^{(9)}$.

In the total of care cases the diagnosis of anxiety was identified in 1,488 of them (15\%). The percentages were very similar between men and women, $15.1 \%$ in the former and $14.9 \%$ in the latter. However, observing the incidence rates it can be verified that the differences are very significant: 19.2 for men and 26.2 for women; these data are consistent with other studies, such as that performed with a sample of preschool children ${ }^{(10)}$, another case was that of university students in Colombia(11) or the multicenter study on 
healthy aging and intellectual disability carried out in the Netherlands(12); all these cases indicate that anxiety disorders occur more frequently in women.

It's amazing the huge difference found in the discovery of this label in the studied centers of $L a$ Linea de la Concepcion municipality. While in health centers was diagnosed in $2.8 \%$ of users, in the hospital was $97.2 \%$. Therefore, it could be assumed: a) that the hospital environment generates in the user more feelings of apprehension or of a vague threat related to the anticipation of an unknown danger, than the health centers do; b) that users with a high level of anxiety go more to hospital emergencies, are more hospitalized and have higher mortality ${ }^{(13)}$; c) that most of the time there are not very specific symptoms, reflecting dissatisfactions or frustrations that can be masked somatically, resulting in a more complex diagnosis, in primary care ${ }^{(14)}$; and d) that nurses working in hospitals elaborate nursing diagnoses more easily than those working in health centers, although no references were found that alluded to this hypothesis.

Regarding the differences in the use of the anxiety label in health centers, our results are in agreement with those found in other studies, in which the identification of this label was much more frequent in hospital care than in primary health care, such as the performed in a pediatric clinic, where $88.5 \%$ of children presented the nursing diagnosis of anxiety ${ }^{(15)}$; or the one performed at the Reina Sofía Hospital in Cordoba (Spain), in which, out of 35,094 users, $17.5 \%$ were diagnosed with anxiety ${ }^{(16)}$; or those performed in areas of primary health care in Tenerife and in La Palma (Spain), in which, out of 117,228 computerized medical health records, only $3.6 \%$ were identified with that label ${ }^{(17)}$.

The "willingness to improve knowledge" label appears in second place in the total care cases and in first place in the age groups of adolescents and adults. However, if we look at the results in Table 5, we find that the incidence of this label is much higher in adults than in adolescents, and also much higher in women than in men; thus, considering the defining characteristics of NANDA-I label, we can assume that women in this age group express more interest in learning, refer to previous knowledge/experiences on a particular subject and present behaviors congruent with the knowledge they possess - all these aspects to a greater extent than men.

In a paper about systematizing an experience in adolescent care ${ }^{(18)}$, the authors identified in first place, in this age group, the label willingness to improve knowledge. Another study, on nursing diagnoses and patient collaboration during the perioperative period(19), carried out in the province of Lampur (Indonesia), also identified the same label in first place; another study carried out in Minas Gerais (Brazil) on nursing diagnoses and interventions in hypertensive and diabetic individuals, according to Orem's theory ${ }^{(20)}$, the label was identified in third place.

The label of risk of infection was identified in third place in the total care cases and among the first three in three age groups (breastfeeding, children and adults). This label mentions a situation in which the person has the risk of being invaded by pathogenic organisms ${ }^{(21)}$. It is advised to use this label only when the behavior of a person or caregiver helps the appearance or persistence of risk factors or when there are external factors that can be eliminated, reduced or changed their effects. The most frequent factors or situations of risk (when nursing professionals can act independently on them) are due to poor knowledge of the person or caregiver on how to avoid exposure to pathogens, inadequate vaccination and increased environmental exposure to pathogens or malnutrition, this depending on degree and cause.

As happened in the anxiety label case, caught our attention that, out of 1,127 cases diagnosed with risk of infection, $31.8 \%$ were diagnosed in health centers and $68.2 \%$ in the hospital. Some authors, coinciding with our study relate as causes identified with the label risk of infection invasive procedures, chronic disease and decreased hemoglobin level; this is the case of a study performed in the postoperative period in patients admitted to surgical units at the University Hospital in the city of Natal (Rio Grande do Norte, Brazil), in which its authors concluded that invasive procedures, skin breakdown and hemoglobin decrease, were factors associated with risk infection ${ }^{(22)}$. In another case, the research was performed with all the users admitted to the Intensive Care Unit in a hospital located in the city Fortaleza (Ceara, Brazil), in which, in addition to the causes identified in the previous study, they also found chronic disease, tissue destruction and increased environmental exposure to pathogens(23). It can be assumed that realization of a greater number of these procedures and a greater presence of these factors, in hospitals, justifies the difference of percentages, so notorious among the care centers. If this is the case, it would have been advisable to acknowledge an interdisciplinary problem, instead of a nursing diagnosis since it is not advisable to use this diagnostic label when the risk factors or situations are related to: chronic disease (diabetes, obesity); inadequate primary defenses, such peristalsis alteration, skin continuity solution, changes in $\mathrm{pH}$ of secretions, decreased ciliary action, premature or prolonged rupture of amniotic membranes, smoking, trauma or tissue destruction; inadequate secondary defenses (decrease in hemoglobin, immunosuppression, 
leukopenia, inflammatory response suppression) and invasive procedures (catheterization, surgery). Precisely, among the inaccuracies in the diagnostic process of nursing, it is important to label as such health problems that cannot be solved independently by the nursing professional or whose solution depends on the treatment prescribed by another professional.

The label Risk of infection was quite present in other researches on nursing diagnoses in the practice of care, such as the one carried out in Brazil on construction and validation of an instrument to systematize nursing care in intensive care ${ }^{(24)}$, in which $100 \%$ of studied users presented this label; or the study carried out in medical units of a hospital in Soria (Spain), in which the risk of infection label was the most prevalent(25).

\section{Limitations}

As limitations of the present investigation it should mentioned that in exploratory ecological studies, like this one, it is necessary to consider the so-called ecological fallacy. Also, since it was a one year study and not a series, it is not possible to estimate the temporal trends of sociodemographic characteristics and the patterns of hospital admissions or consultations in health centers. The study intended to make a fixed photo with a crosssectional cut as a working methodology to obtain an overview that would be utilized as a starting point for future studies. This was a cross-sectional study, and thus does not present results regarding stability, sensitivity to change or predictive validity; to obtain those results a longitudinal approach would have been required.

Another limitation of this study would have been not to consider hospital readmissions or repeated consultations in health centers. For this reason, it has been useful to have as a clear indicator the care case. Because what is reported are "episodes", it cannot be known the number of times a person is attended in health care centers.

Another possible limitation of results could be related to the quality of the databases from which the particularities of the welfare cases were obtained; this quality depends on the reliability of personal data, correct classification and coding of NANDA diagnoses and on number of users to whom the nursing methodology is applied; which in turn depends on the institution's adherence and compliance with rules.

\section{Contribution to the Advancement of Nursing Knowledge}

This study aims to contribute to the advancement of nursing knowledge, allowing the professional development of nursing in the following aspects: 1) planning of nursing care for a particular population, detecting their needs for care; 2) implementation and improvement of work with the most prevalent nursing diagnoses; 3) planning essential contents for undergraduate and postgraduate courses, in different nursing care scenarios; and 4) prioritize development of protocols and standardization of care plans.

\section{Conclusions}

All age groups showed a higher prevalence of care episodes in women. Women greater morbidity and longer life expectancy are issues that continue to generate countless investigations that often do not provide conclusive results.

This research allowed to detect, through NANDA-I, answers to health problems of greater incidence in users attended in the Health Management of La Línea de la Concepción municipality: anxiety, willingness to improve knowledge and risk of infection.

It would be necessary to explore, in future studies, the causes and clinical manifestations related to the diagnostic label of anxiety; this due to the high prevalence of this diagnosis in all age groups.

Given the prevalence of "risk of infection" diagnosis, we can conclude that prevention activities should be a fundamental element among nursing professionals; therefore it is necessary to adequate resources for this objective.

\section{References}

1. Paans W, Sermeus W, Nieweg RM, Krijnen WP, van der Schans CP. Do knowledge, knowledge sources and reasoning skills affect the accuracy of nursing diagnoses? a randomised study. BMC Nurs. 2012; 11:11. doi: http://dx.doi.org/10.1186/1472-6955-11-11

2. Rodríguez-Acelas A, Cañón-Montañez W. Methodological roads: development and validation of nursing diagnoses. Rev Cuid. 2015; 6(1): 879-81. doi: http://dx.doi. org/10.15649/cuidarte.v6i1.248

3. Manterola C, Otzen T. Observational Studies. The Most Commonly Used Designs in Clinical Research. Int. J. Morphol. 2014; 32(2): 634-45. doi: http://dx.doi. org/10.4067/S0717-95022014000200042

4. Martínez N. Nursing in the universal health coverage: new terms and old actions. Rev Cubana Salud Pública [Internet]. 2015 [cited Oct 03, 2016];41(Suppl 1). Available from: http://scielo.sld.cu/scielo.php?script=sci_ arttext\&pid=S0864-34662015000500008\&lng=es .

5. Santos RB, Duran E, Carmona ECM, Melo LL, Beck ARM. Nursing diagnoses in patients with hospital 
infection. J Nurs UFPE on line [Internet]. 2015 Sept [cited Oct 01, 2016]; 9 (Supl.8): 9359-65. Available from: http://www.revista.ufpe.br/revistaenfermagem/ index.php/revista/article/view/7461/pdf_8623

6. Ferreira AM, Rocha EN, Lopes CT, Bachion MM, Lopes JL, Barros LBL. Nursing diagnoses in intensive care: cross-mapping and NANDA-I taxonomy. Rev Bras Enferm. 2016; 69(2):307-15. doi: http://dx.doi. org/10.1590/0034-7167.2016690214i

7. Castellan C, Sluga S, Spina E, Sanson G. Nursing diagnoses, outcomes and interventions as measures of patient complexity and nursing care requirement in Intensive Care Unit. J Adv Nurs. 2016 Jun; 72 (6): 1273-86. doi: http://dx.doi.org/10.1111/jan.12913

8. Almonacid CI, Ramos AJ, Rodríguez-Borrego M. Level of anxiety versus self-care in the preoperative and postoperative periods of total laryngectomy patients. Rev. Latino-Am. Enfermagem. [Internet].2016 [cited Oct 9, 2016];24:e2707. Available from: http://www. scielo.br/scielo.php?script=sci_arttext\&pid=S0104$11692016000100338 \&$ Ing=en. Epub June 14, 2016.

9. Somerville S, Dedman K, Hagan R, Oxnam E, Wettinger M, Byrne S, et al. The Perinatal Anxiety Screening Scale: development and preliminary validation. Arch Womens Ment Health. 2014 Oct; 17 (5): 443-54. doi: http:// dx.doi.org/10.1007/s00737-014-0425-8

10. Franz L, Angold A, Copeland W, Costello EJ, ToweGoodman N, Egger H. Preschool Anxiety Disorders in Pediatric Primary Care: Prevalence and Comorbidity.

J Am Acad Child Adolesc Psychiatry. 2013 Dec; 52 (12): 1294-303.e1. doi: http://dx.doi.org/10.1016/10.1016/j. jaac.2013.09.008

11. Vélez DMA, Garzón CPC, Ortíz DLS. Anxiety and depression characteristics in university students. Int J Psychol Res. 2008; 1(1): 34-9. doi: http://dx.doi. org/10.21500/issn.2011-2084

12. Hermans H, Beekman ATF, Evenhuis HM. Prevalence of depression and anxiety in older users of formal Dutch intellectual disability services. J Affect Disord. 2013 Jan 10; 144 (1-2): 94-100. doi: http://dx.doi.org/10.1016/j. jad.2012.06.011

13. Torrents R, Ricart M, Ferreiro M, López A, Renedo L, Lleixà $M$ et al. Anxiety. A review from Mishel's theory. Index Enferm. 2013;22(1-2):60-4. doi: http://dx.doi. org/10.4321/S1132-12962013000100013.

14. Latorre JM, Navarro B, Parra M, Martín J, Mae C, Cano A. Assessment and intervention of Anxiety and Depression disorders in Primary Care: An unsolved problem. Rev Clin Med Fam. 2016; 5(1): 37-45. doi: http://dx.doi.org/10.4321/S1699-695X2012000100007 15. Gomes GLL, Nóbrega MML. Anxiety in children following hospitalization: a proposal for a nursing diagnosis. Rev. Latino-Am. Enfermagem. [Internet]. 2015 Sept/Oct. [cited
Oct 8, 2016]; 23(5):963-970. Available from: http:// www.scielo.br/scielo.php?script=sci_arttext\&pid=S010411692015000500963\&lng=en.

16. Medina MJ, Rodríguez MA, Giménez R. Description and Analysis of the application level of the computer program of care, Azahar, in the University Hospital Reina Sofia in Cordoba. New Performance approach. Enfermería Global. [Internet]. 2008 Jun [cited Feb 10, 2016];7(2):1-9. Available from: http://revistas.um.es/ eglobal/article/view/16071

17. Brito PR, Rodríguez M, Toledo C. Problemas NANDA del dominio psicosocial más frecuentes en atención primaria. ENE-revista de enfermería. [Internet]. 2009 Apr [cited Mar 2, 2016];3(1):42-51. Available from: http://ene-enfermeria.org/ojs/index.php/ENE/article/ viewFile/156/139

18. García A, Ibáñez LE. Systematization of a care experience with adolescents. Ciencia y Cuidado. [Internet]. 2015 Sept [cited Oct 08, 2016];10(2):6575. Available from: http://revistas.ufps.edu.co/ojs/ index.php/cienciaycuidado/article/view/246/267

19. Suarni L, Nurjannah I, Apriyani H. Nursing and collaborative diagnoses on perioperative patients with and without using six steps of diagnostic reasoning methods. Int J Res Med Sci. 2015;3 (Suppl 1):S97-103. doi: http:// dx.doi.org/10.18203/2320-6012.ijrms20151528

20. Camara de Moura P, Muniz L, Santana C, Vilela N, Lopes $M D$, Assunção LV. Diagnoses and nursing interventions in hypertensive and diabetic individuals according to Orem's Theory. Rev Rene. 2014;15(6):1039-46. doi: http:// dx.doi.org/10.15253/2175-6783.2014000600018

21. Dias de Araújo D, Rodrigues de Carvalho RL, Machado TC. Diagnoses identified in the medical records of hospitalized elderly. Invest Educ Enferm. 2014; 32(2): 225-35. doi: https://www.ncbi.nlm.nih.gov/ pubmed/25230033

22. Botarelli FR, Queiroz QJR, Fernandes APNL, Araújo JNM, Ferreira-Júnior MA, Vitor AF. Nursing diagnosis risk of infection in patients in the postoperative period: a cross-sectional study. Online braz $\mathrm{j}$ nurs [Internet]. 2016 June [cited Oct 7, 2016];15(2):245-53. Available from: http://www.objnursing.uff.br/index.php/nursing/ article/view/5299

23. Guimaraes RK, De Oliveira MV. Nursing diagnose in individuals admitted to the intensive therapy unit. av.enferm. [Internet]. 2013 July [cited Oct 7, 2016];31(2):74-82. Available from: http://www.scielo. org.co/scielo.php?script=sci_arttext\&pid=S012145002013000200008\&lng=en.

24. Araújo DS, França AF, Mendonça JKS, Bettencourt ARC, Amaral TLM, Prado PR. Construction and validation of a systematization instrument for nursing in intensive 
care. Rev Rene. 2015; 16(4):461-9. doi: http://dx.doi. org/10.15253/2175-6783.2015000400002

25. Buergo O. Analysis of the implantation of Plans of Cares, through GACELA, in the medical units of the Hospital Santa Barbara of Soria. NURE Inv. [Internet]. 2013 Sept/Oct [cited Oct 5, 2016];10(65): Available from: http://web2014.fuden.es/FICHEROS_ADMINISTRADOR/

ORIGINAL/NURE66_original_gacela.pdf

Corresponding Author: Rafael González Rodríguez

Universidad de Cádiz. Facultad de Enfermería

Ctra. de Getares. C/ Venus, s/n

CEP: 11207, Algeciras, Cádiz, Espanha

E-mail: rgonzalez.rodriguez@uca.es
Copyright (c) 2017 Revista Latino-Americana de Enfermagem This is an Open Access article distributed under the terms of the Creative Commons (CC BY).

This license lets others distribute, remix, tweak, and build upon your work, even commercially, as long as they credit you for the original creation. This is the most accommodating of licenses offered. Recommended for maximum dissemination and use of licensed materials. 